\title{
Studies of mechanical properties of treated bamboo
}

\section{S.P. KURHEKAR}

\begin{abstract}
Steeping method was used for treating bamboo by using Boric acid Borax, Copper Chrome Boron and Cashew Nut Shell Liquid.Treatment was carried out for 14 day. After treatment, quality evaluation of bamboo was done by cutting bamboo in sample size of $61 \mathrm{~cm}\left(2^{\prime}\right)$ and exposing them to environmental condition. Mechanical properties of $61 \mathrm{~cm}\left(2^{\prime}\right)$ bamboo (30.5 cm (1') buried in soil and $30.5 \mathrm{~cm}\left(1^{\prime}\right)$ above soil were determined by using universal testing machine.After preservation time of 14 days it was observed, out of 20 lit of sample, 10 lit Boric Acid Borax liquid, 5 lit of Copper Chrome Boron liquid was absorbed by bamboo and cashew nut shell liquid was not absorbed by bamboo specimens. It was observed that for the tensile strength for bamboo treated with Boric Acid Borax, Copper Chrome Boron and Cashew Nut Shell Liquid was $38.20 \mathrm{~N} / \mathrm{mm}^{2}, 30.69 \mathrm{~N} / \mathrm{mm}^{2}$ and $8.03 \mathrm{~N} / \mathrm{mm}^{2}$ for under soil and $48.09 \mathrm{~N} / \mathrm{mm}^{2}, 39.09 \mathrm{~N} / \mathrm{mm}^{2}$ and 9.35 for over soil sample and compressive strength was $5.04 \mathrm{~N} / \mathrm{mm}^{2}, 4.02 \mathrm{~N} / \mathrm{mm}^{2}$ and $0.39 \mathrm{~N} / \mathrm{mm}^{2}$ for under soil sample and $5.17 \mathrm{~N} / \mathrm{mm}^{2}, 4.87 \mathrm{~N} /$ $\mathrm{mm}^{2}$ and $0.58 \mathrm{~N} / \mathrm{mm}^{2}$ for over soil sample.
\end{abstract}

KEY WORDS : Bamboo, Treatment, Mechanical properties

How to cite this Article : Kurhekar, S.P. (2014). Studies of mechanical properties of treated bamboo. Engg. \& Tech. in India, 5 (1\&2) : 44-48. 